\title{
The relative susceptibility of four cephalosporins to a beta-lactamase from Bacillus cereus
}

\author{
A. D. RUSSELL AND J. R. FURR \\ From the Welsh School of Pharmacy, University of Wales Institute of Science and Technology, \\ Cathays Park, Cardiff
}

SYNOPSIS The effects of purified beta-lactamase from Bacillus cereus on the activity of four cephalosporins are described. Drug inactivation was measured spectrophotometrically and confirmed by microbiological assay and by microbiological techniques involving determinations of minimum inhibitory concentrations and growth curves of Staphylococcus aureus NCTC 6571 (Oxford) in broth containing drug \pm enzyme. Cephaloridine was the most sensitive of the four cephalosporins, followed by cephalothin and the sodium salt of 7-cyanacetamidocephalosporanic acid, with cephalexin considerably resistant to inactivation. The possible use of this beta-lactamase in the sterility testing of cephaloridine and cephalothin is examined.

Cephalosporins are more resistant to beta-lactamases from Gram-positive bacteria such as staphylococci than are benzylpenicillin, phenoxymethylpenicillin, or ampicillin (Pollock, 1967), although the relative instability of cephaloridine to staphylococcal penicillinase has been described (Benner, Bennett, Brodie, and Kirby, 1965 ; Ridley and Phillips, 1965). Kuwabara and Abraham (1967) have reported that the zinc-dependent beta-lactamase II enzyme, obtained from a strain of Bacillus cereus preferentially destroyed cephalosporins.

In this paper, we describe the comparative susceptibility of four cephalosporins to a highly purified commercial beta-lactamase obtained from $B$. cereus and show some possible laboratory uses.

\section{Methods}

\section{ANTIBIOTICS}

These were the sodium salt of 7-cyanacetamidocephalosporanic acid (Cephacetrile (CAA), a gift from Ciba Laboratories, Horsham, Sussex) and cephaloridine, cephalothin, and cephalexin, which were kindly provided by Glaxo Research Laboratories Ltd, Greenford, Middlesex.

BETA-LACTAMASE PREPARATION

This was an injectable preparation of a highly purified freeze-dried form of $B$. cereus penicillinase, as an 800000 unit vial (Neutrapen, Riker

Received for publication 1 June 1973.
Laboratories, Loughborough, Leicestershire). One unit inactivates 1 unit of benzylpenicillin per min at $25^{\circ} \mathrm{C}$ and $\mathrm{pH} 7$.

\section{HYDROLYSIS OF CEPHALOSPORINS}

Solutions $\left(2 \times 10^{-4} \mathrm{M}\right)$ of cephalosporins in $6.7 \times 10^{-3} \mathrm{M}$ phosphate buffer, $\mathrm{pH} 7 \cdot 0$, were mixed with equal volumes of Neutrapen solutions in this buffer, all solutions having previously been allowed to equilibrate at $37^{\circ} \mathrm{C}$. Changes in extinction at $255 \mathrm{~nm}$ for cephaloridine (O'Callaghan, Kirby, and Wishart, 1968; Jack and Richmond, 1970) and at 260, 263, and $263 \mathrm{~nm}$, respectively, for cephalothin, cephalexin, and CAA during subsequent incubation at $37^{\circ} \mathrm{C}\left(+0.1^{\circ} \mathrm{C}\right)$ were followed by means of an automatic SP 600 recording spectrophotometer fitted with a temperature control. The blank cell contained buffer only.

\section{ASSAYS}

A biological assay was used to determine the effect of Neutrapen $(0,160$ or 320 units/ml, final concentration) on the four cephalosporins $(25 \mu \mathrm{g} / \mathrm{ml}$ final concentration) in buffer, $\mathrm{pH} 7$, at $37^{\circ} \mathrm{C}$. Residual antibiotic activity was determined, after quenching enzyme action in aliquots by iodine (O'Callaghan, Morris, Kirby, and Shingler, 1972), by the agar (Oxoid Ltd, London) cup-plate method, using Bacillus subtilis NCTC 8236 as test organism.

These were undertaken on the four cephalosporins 
in the presence and absence of Neutrapen using Nujol as a vehicle on sodium chloride plates. In addition, a potassium bromide disc was used with the CAA-Neutrapen mixture. Analyses were made with the Perkin-Elmer 397 infrared spectrophotometer, using a normal slit width and medium scan speed.

\section{BACTERIAL GROWTH}

The test organism, Staphylococcus aureus NCTC 6571 (Oxford), was grown overnight at $37^{\circ} \mathrm{C}$ in $10 \mathrm{ml}$ broth (Oxoid Ltd, London). Minimum inhibitory concentrations (MICs) of the drugs were determined as follows: $0.2 \mathrm{ml}$ of overnight $S$. aureus cultures were added to $10 \mathrm{ml}$ broth containing various concentrations of a cephalosporin \pm Neutrapen. The presence or absence of growth was noted after incubation for 24 hours at $37^{\circ} \mathrm{C}$.

The effect of cephalosporins on the rate of growth of $S$. aureus in broth was determined as follows: $1 \mathrm{ml}$ of an overnight $37^{\circ} \mathrm{C}$ broth culture was added to $39 \mathrm{ml}$ broth (prewarmed to $37^{\circ} \mathrm{C}$ ) containing the desired drug concentration \pm Neutrapen. Growth during subsequent incubation at $37^{\circ} \mathrm{C}$ was followed by means of a Unicam SP 600 spectrophotometer at a wavelength of $660 \mathrm{~nm}$. This wavelength was chosen because of the red colour (absorption maximum $550 \mathrm{~nm}$ ) which occurs when CAA is incubated with some beta-lactamases, including Neutrapen (Russell, 1972).

STERILITY TEST OF CEPHALORIDINE, CEPHALOTHIN, AND CAA

Various quantities of Neutrapen were added to broth (final volume $10 \mathrm{ml}$ ) containing $50 \mathrm{mg}$ of an antibiotic. After incubation for one hour at $30^{\circ} \mathrm{C}$ (British Pharmacopoeia, 1968), 0.1 ml (50-100 viable cells) of a $10^{-8}$ dilution of an overnight $30^{\circ} \mathrm{C}$ culture of $S$. aureus 6571 was added, the containers were incubated at $30^{\circ} \mathrm{C}$, and the presence or absence of growth was noted during a subsequent seven-day incubation at $30^{\circ} \mathrm{C}$.

COLONY FORMATION OF S. aureus

Of a 1 in $10^{7}$ dilution of an overnight $37^{\circ} \mathrm{C}$ broth culture $0.1 \mathrm{ml}$ was spread onto dried agar plates containing a cephalosporin \pm Neutrapen. Colonies were counted after incubation for 48 hours at $37^{\circ} \mathrm{C}$.

\section{Results}

The rates of inactivation of the four cephalosporins by Neutrapen are shown in figure $1 \mathrm{a}, \mathrm{b}, \mathrm{c}, \mathrm{d}$. These results indicated that cephaloridine is the most rapidly hydrolysed, followed by cephalothin and CAA, with cephalexin the most resistant. The results (table I) of the biological assays, in which a cephalosporin was treated for 15 and 30 min with 160 or 320 units/ml of Neutrapen, support this finding.

Infrared spectrophotometric analyses suggested that the decrease in extinction (fig 1) at the stated wavelengths was the result of an opening of the beta-lactam ring by enzyme attack.

\begin{tabular}{lcccc}
\hline Antibiotic & $\begin{array}{l}\text { Time } \\
\text { (min) }\end{array}$ & \multicolumn{2}{l}{$\begin{array}{l}\text { Percentage Antibiotic Remaining } \\
\text { after Incubation with Neutrapen } \\
(\text { units/ml })^{1}\end{array}$} \\
\cline { 2 - 5 } & & 0 & 160 & 320 \\
\hline Cephaloridine & 15 & 104 & $22 \cdot 8$ & \\
Cephalothin & 30 & 104 & & \\
& 15 & 108 & $70 \cdot 4$ & $70 \cdot 4$ \\
CAA & 30 & 108 & 76 & $73 \cdot 2$ \\
Cephalexin & 15 & 100 & $98 \cdot 5$ & \\
\hline
\end{tabular}

Table I Rates of inactivation of four cephalosporins by Neutrapen in phosphate buffer, $\mathrm{pH} 7$, at $37^{\circ} \mathrm{C}$

${ }^{1}$ Initial antibiotic concentration $25 \mu \mathrm{g} / \mathrm{ml} ;{ }^{2} \mathrm{Nd}$ no destruction

\section{GROWTH OF $S$. aureus}

The MICs of cephaloridine, cephalothin, cephalexin, and CAA against $S$. aureus were $0.05,0.5$, $5-10$, and $0.5 \mu \mathrm{g} / \mathrm{ml}$ respectively. The effects of various concentrations of Neutrapen on 25 and $50 \mu \mathrm{g} / \mathrm{ml}$ of a cephalosporin in broth inoculated with $S$. aureus are shown in table II. Cephaloridine is obviously the most sensitive of the four drugs to Neutrapen; CAA is rather more resistant than is cephalothin, whereas cephalexin shows a very high resistance to breakdown by this beta-lactamase. These findings confirm those shown in figure 1.

Table III describes colony formation of $S$. aureus on agar containing a cephalosporin \pm Neutrapen. No colonies developed on plates containing 25 or

\begin{tabular}{|c|c|c|}
\hline Antibiotic & $\begin{array}{l}\text { Concentration } \\
(\mu g / m l)\end{array}$ & $\begin{array}{l}\text { Minimum Concentration of } \\
\text { Neutrapen (units/ml) to Overcome } \\
\text { Growth-inhibitory Activity }\end{array}$ \\
\hline Cephaloridine & $\left.\begin{array}{l}25 \\
50\end{array}\right\}$ & Between 0 and 40 \\
\hline Cephalothin & $\begin{array}{l}25 \\
50\end{array}$ & $\begin{array}{l}80 \\
80-160\end{array}$ \\
\hline CAA & $\begin{array}{l}25 \\
50\end{array}$ & $\begin{array}{l}160 \\
320\end{array}$ \\
\hline Cephalexin & $\begin{array}{l}25 \\
50\end{array}$ & $\begin{array}{l}2400 \\
3200\end{array}$ \\
\hline
\end{tabular}

Table II Effect of Neutrapen on the growth-inhibitory activity of four cephalosporins against $\mathrm{S}$. aureus in broth at $37^{\circ} \mathrm{C}$ 

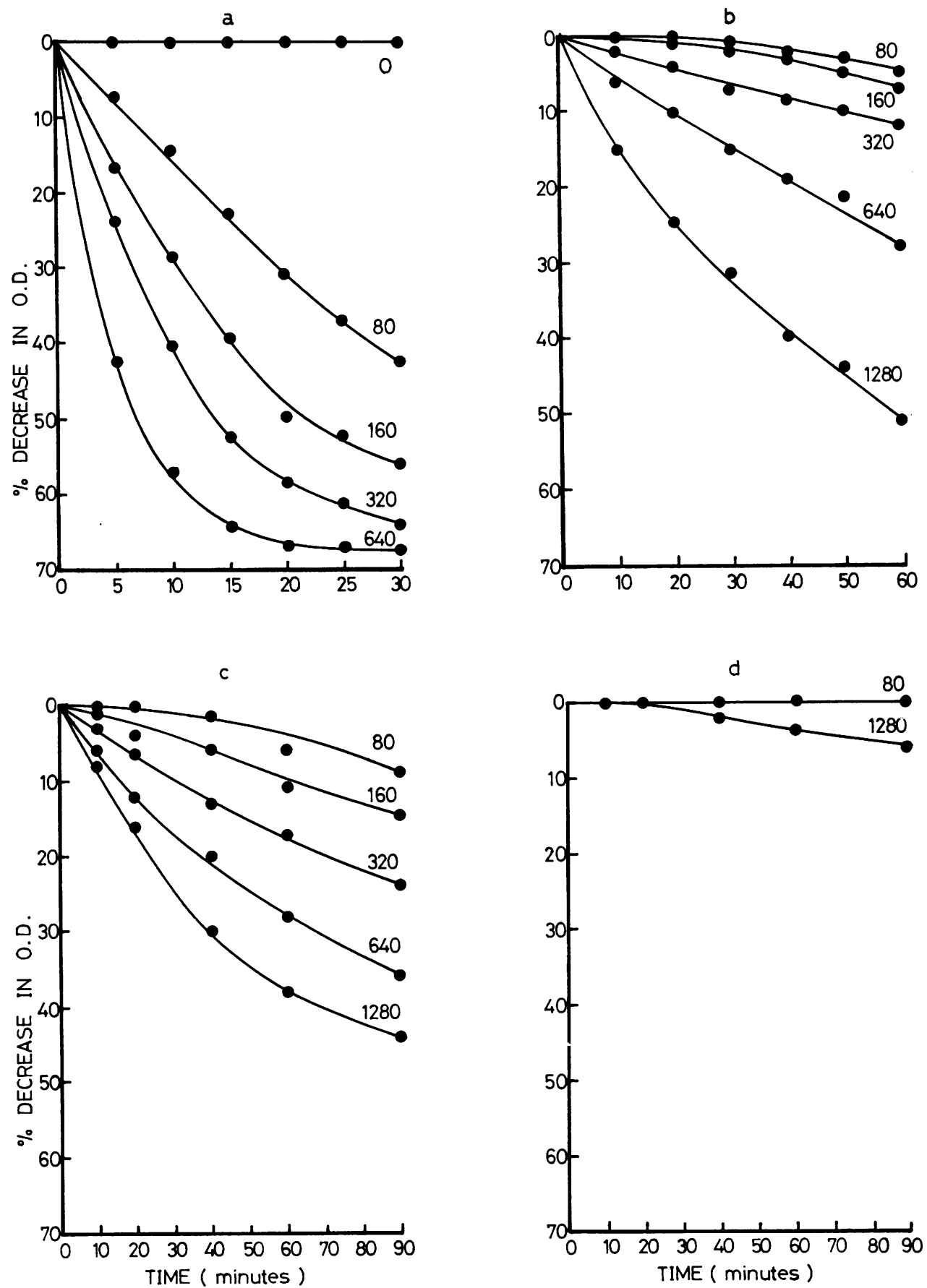

Fig 1 Neutrapen-induced inactivation of four cephalosporins $\left(10^{-4} \mathrm{M}\right.$, final concentration) as measured by changes in extinction at the stated wavelength: (a) cephaloridine, $255 \mathrm{~nm}$ (b) cephalothin, $260 \mathrm{~nm}$ (c) CAA, $263 \mathrm{~nm}$ (d) cephalexin, $263 \mathrm{~nm}$. Figures are enzyme concentration (units/ml) 


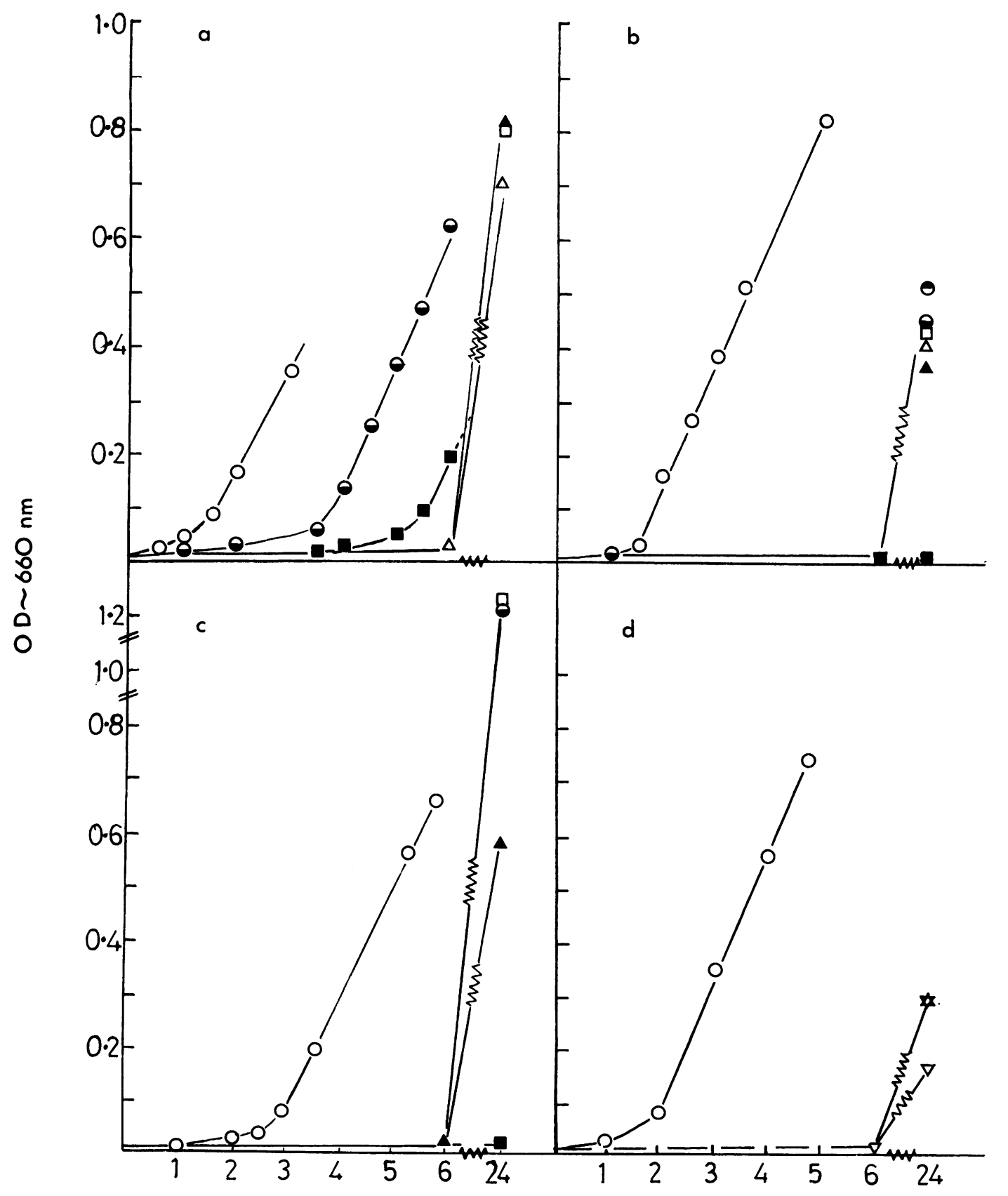

TIME HR

Fig 2 Rate of growth of S. aureus in broth containing 25 or $50 \mu \mathrm{g} / \mathrm{ml}$ of (a) cephaloridine, (b) cephalothin, (c) CAA, (d) cephalexin. Antibiotic $25 \mu \mathrm{g} / \mathrm{ml}$ and Neutrapen (units/ml) 80, $\triangle-\triangle ; 160, \triangle-\triangle$; $320, \square-\square ; 1280, \nabla-\nabla$. Antibiotic $50 \mathrm{\mu g} / \mathrm{ml}$ and Neutrapen (units/ml) 160 ,

320 , 640, 


\begin{tabular}{lllc}
\hline Antibiotic & $\begin{array}{l}\text { Concentration } \\
(\mu \mathrm{g} / \mathrm{ml})\end{array}$ & $\begin{array}{l}\text { Neutrapen } \\
\text { Concentration } \\
(\text { units } / \mathrm{ml})\end{array}$ & $\begin{array}{l}\text { Colonies at } \\
48 \text { Hours }\end{array}$ \\
\hline \multirow{4}{*}{ Cephaloridine } & 50 & 0 & 0 \\
& 50 & 25 & 195 \\
& 50 & 50 & 205 \\
& 50 & 75 & 420 \\
Cephalothin & 50 & 100 & 408 \\
(or CAA) & 50 & 250 & 0 \\
Cephalexin & 50 & 0 & 0 \\
None & 25 & 50 or 100 & 0 \\
\hline
\end{tabular}

Table III Effect of Neutrapen concentration on colony formation of S. aureus 6571 on nutrient agar containing a cephalosporin

$50 \mu \mathrm{g} / \mathrm{ml}$ cephaloridine, but colony formation on plates containing cephaloridine + enzyme. No colonies were produced on agar containing Neutrapen and 25 or $50 \mu \mathrm{g} / \mathrm{ml}$ of CAA, cephalothin, or cephalexin.

The rate of growth at $37^{\circ} \mathrm{C}$ of $S$. aureus in broth containing 25 or $50 \mu \mathrm{g} / \mathrm{ml}$ of a cephalosporin and varying concentrations of Neutrapen is shown in figure 2. Growth in broth containing Cephaloridine plus the higher concentrations of Neutrapen begins within the first five hours; in contrast, no visible growth of the organism occurs within this period in broth containing Neutrapen plus CAA or cephalothin, and virtually no growth after $24 \mathrm{hr}$ when cephalexin replaces the other cephalosporins.

Table IV describes the results of the sterility tests carried out at $30^{\circ} \mathrm{C}$ with the three injectable products, cephaloridine, cephalothin, and 7-cyanacetamidocephalosporanic acid. Similar results were obtained at $37^{\circ} \mathrm{C}$. Low concentrations of Neutrapen were needed to inactivate a $50 \mathrm{mg}$ sample of cephaloridine, but these could not inactivate cephalothin and CAA to such an extent as to allow $S$. aureus to grow within the seven-day incubation period, although higher Neutrapen concentrations also inactivated cephalothin. Samples from those containers showing growth were tested for their Gram-staining reaction, cultural purity, and sensitivity to betalactam antibiotics: no differences from the parent culture were observed.

\begin{tabular}{|c|c|c|c|c|}
\hline \multirow[t]{2}{*}{$\begin{array}{l}\text { Cephalosporin } \\
(50 \mathrm{mg} / 10 \mathrm{ml})\end{array}$} & \multicolumn{4}{|c|}{$\begin{array}{l}\text { Minimum Concentration of Neutrapen }(u / m l) \\
\text { Allowing Growth after (days) }\end{array}$} \\
\hline & One & Three & Five & Seven \\
\hline $\begin{array}{l}\text { Cephaloridine } \\
\text { Cephalothin } \\
\text { CAA }\end{array}$ & $\begin{array}{r}9000 \\
>80000 \\
>90000\end{array}$ & $\begin{array}{r}1000 \\
40000 \\
>90000\end{array}$ & $\begin{array}{r}500 \\
20000 \\
>90000\end{array}$ & $\begin{array}{r}200 \\
5000 \\
>90000\end{array}$ \\
\hline
\end{tabular}

Table IV Sterility testing of three cephalosporins

${ }^{1} \mathrm{Of} S$. aureus NCTC 6571 at $30^{\circ} \mathrm{C}$

\section{Discussion}

Our initial interest in studying the effect of this enzyme on the four cephalosporins was to determine whether Neutrapen could be used $(a)$ as a simple inactivating agent (Russell, 1964) in performing viable counts on cephalosporin-treated bacteria; (b) as an inactivating agent in sterility testing of cephalosporins. The results shown in figs 1 and 2 and tables I-IV indicate that cephaloridine is quite sensitive to inactivation by Neutrapen which confirms and extends the findings of Newsom and Walsingham (1973), whereas CAA, cephalothin, and especially cephalexin are more resistant. Low concentrations of Neutrapen, are needed for colony formation of $S$. aureus in agar containing cephaloridine, and Neutrapen appears to be suitable for use as an inactivating agent in the sterility testing (Russell and Gilbert, 1964) of cephaloridine, and possibly of cephalothin, but not of 7-cyanacetamidocephalosporanic acid. Cephalexin is given orally, and no sterility test was thus made with this compound. The present pharmacopoeial method of testing 'penicillinase-resistant' beta-lactam antibiotics is to use a filtration technique. From the results presented here and from those of Newsom and Walsingham (1973) it seems that this could be supplemented by an inactivation method for cephaloridine and even for methicillin.

\section{References}

Benner, E. J., Bennett, J. V., Brodie, J. L., and Kirby, W. M. M (1965). Inactivation of cephalothin and cephaloridine by Staphylococcus aureus. J. Bact., 90, 1599-1604.

British Pharmacopeia (1968). Pharmaceutical Press, London.

Jack, G. W., and Richmond, M. H. (1970). A comparative study of eight distinct $\beta$-lactamases synthezised by Gram-negative bacteria. J. gen. Microbiol., 61, 43-61.

Kuwabara, S., and Abraham, E. P. (1967). Some properties of two extracellular $\beta$-lactamases from Bacillus cereus $569 /$ H. Biochem. $J ., 103,27 C$.

Newsom, S. W. B., and Walsingham, B. M. (1973). The use of $\beta$ lactamases in the clinical laboratory.J. med. Microbiol., 6, 59-66.

O'Callaghan, C. H., Kirby, S. M., and Wishart, D. R. (1968). Microbiological assay of mixed cephalosporins. Antimicrob. Agents and Chemother., 1967, 716-722.

O'Callaghan, C. H., Morris, A., Kirby, S. M., and Shingler, A. H. (1972). Novel method for detection of $\beta$-lactamases by using a chromogenic cephalosporin substrate. Antimicrob. Agents and Chemother., 1, 283-288.

Pollock, M. R. (1967). Origin and function of penicillinase: a problem in biochemical evolution. Brit. med. J., 4, 71-77.

Ridley, M., and Phillips, I. (1965). Relative instability of cephaloridine to staphylococcal penicillinase. Nature (Lond.), 208, 1076-1078.

Russell, A. D. (1964). Damaged bacteria: recovery and revival. Lab. Pract., 13, 114-122.

Russell, A. D. (1972). Interaction of a new cephalosporin, 7-cyanacetamidocephalosporanic acid, with some Gram-negative and Gram-positive $\beta$-lactamase-producing bacteria. Antimicrob. Agents and Chemother., 2, 255-260

Russell, A. D., and Gilbert, R. J. (1964). The sterility testing of pharmaceutical products. Mfg. Chem. and Aerosol News, 35, $34-42$. 